\title{
Pemasangan Paving Block Lapangan Olah Raga Sekolah Menengah Kejuruan Aviasi Branti - Lampung
}

\author{
Sukamto $^{1}$, Riyanto Saputro ${ }^{2}$, Oka Fatra ${ }^{3}$, Yenni Arnas ${ }^{4}$, Ika Endrawijaya ${ }^{5}$ \\ 1,2,3,4,5,6 Politeknik Penerbangan Indonesia Curug \\ e-mail: ${ }^{1}$ sukamto@ppicurug.ac.id, ${ }^{2}$ riyanto.saputro@ppicurug.ac.id, ${ }^{3}$ oka.fatra@ppicurug.ac.id \\ ${ }^{3}$ yenni.arnas@ppicurug.ac.id, ${ }^{5}$ ika.endrawijaya@ ppicurug.ac.id
}

\begin{abstract}
Abstrak
Sekolah Menengah Kejuruan (SMK) Aviasi Branti - Lampung merupakan sekolah menengah kejuruan di bidang penerbangan yang baru berdiri dengan jumlah siswa 95 orang. Pembinaan kemampuan siswa tidak hanya dibatasi pada kegiatan pembelajaran yang mendukung kompetensi siswa di bidang penerbangan, namun juga dibutuhkan kemampuan lain yang turut mendukung tercapainya kompetensi utama. Kondisi fisik yang prima dan interaksi yang terjadi selama siswa melaksanakan kegiatan olah raga merupakan salah satu sarana yang dapat dimanfaatkan untuk mendukung kompetensi utama siswa. Politeknik Penerbangan Indonesia Curug melalui kegiatan pengabdian kepada masyarakat melakukan kegiatan pemasangan paving block pada lapangan olah raga di SMK Aviasi Branti Lampung untuk meningkatkan kualitas fasilitas lapangan olah raga bola voli yang telah ada. Pemasangan paving block dilakukan dilaksanakan selama 2 hari melibatkan civitas akademika SMK Aviasi Branti - Lampung dibantu oleh tenaga profesional setempat. Keberadaan fasilitas lapangan olahraga bola voli yang layak diharapkan dapat meningkatkan interaksi antar siswa, guru dan masyarakat di sekitar sekolah serta meningkatkan kebugaran tubuh dalam rangka menunjang keberhasilan belajar mengajar di sekolah.
\end{abstract}

Kata Kunci : paving block, sarana olah raga, interaksi siswa, kebugaran.

\begin{abstract}
Aviasi Branti Vocational High School (SMK) - Lampung is a newly established vocational high school in the field of aviation with 95 students. Development of student abilities is not only limited to learning activities that support student competencies in the field of aviation, but also requires other abilities that support the achievement of key competencies. Good physical conditions and the interactions that occur while students carry out sports activities are one of the means that can be used to support students' main competencies. Politeknik Penerbangan Indonesia Curug through community service activities carried out the installation of paving blocks on the sports field at SMK Aviasi Branti Lampung to improve the quality of the existing volleyball sports field facilities. Installation of paving blocks was carried out for 2 days involving the academic community of SMK Aviasi Branti Lampung, assisted by local professionals. The existence of proper volleyball sports field facilities is expected to increase interaction between students, teachers and the community around the school as well as improve physical fitness in order to support the success of teaching and learning in schools.
\end{abstract}

Keywords : paving blocks, sports facilities, student interaction, fitness.

\section{Pendahuluan}

Sekolah Menengah Kejuruan (SMK) Penerbangan masuk dalam rumpun Teknologi dan Rekayasa sebagai salah satu tahapan pendidikan vokasi tingkat menengah atas yang berpotensi mengasilkan lulusan siap kerja. Kondisi tersebut sesuai dengan Pasal 3 UU No. 20 Tahun 2003 Tentang Sistem Pendidikan Nasional, dimana pendidikan nasional berfungsi mengembangkan kemampuan dan membentuk watak serta peradaban bangsa yang bermartabat dalam rangka mencerdaskan kehidupan bangsa, 
bertujuan untuk berkembangnya potensi peserta didik agar menjadi manusia yang beriman dan bertakwa kepada Tuhan Yang Maha Esa, berakhlak mulia, sehat, berilmu, cakap, kreatif, mandiri, dan menjadi warga negara yang demokratis serta bertanggung jawab". Sedangkan Pasal 15 pada undang-undang tersebut menjelaskan SMK merupakan "Pendidikan kejuruan menengah yang mempersiapkan peserta didik terutama untuk bekerja pada bidang tertentu".

SMK aviasi Branti adalah salah satu sekolah menengah kejuruan yang mencetak calon tenaga teknisi di bidang penerbangan khususnya perawatan pesawat terbang. Sekolah ini mendidik para siswa dari keluarga yang kurang mampu maupun yang berstatus siswa yatim piatu. Tahun ajaran 2020/2021 ini merupakan tahun ajaran perdana bagi SMK Aviasi Branti, namun demikian antusiasme masyarakat demikian besar. Jumlah peserta didik telah mencapai kuota 3 kelas dengan masing-masing kelas berkapasitas 32 orang.

Pada tahun perdana berdiri, SMK Aviasi Branti menggunakan fasilitas dari Balai Riset Kemneterian Perindustrian yang direnovasi sedemikian rupa bangunan yang ada untuk kebutuhan kelas dan perkantoran. Saat ini kegiatan kelas dapat dilakukan dengan fasilitas yang ada, namun belum memiliki fasilitas lapangan yang cukup representatif untuk melakukan kegiatan upacara dan kegiatan luar kelas lainnya karena kalau hujan becek dan pada waktu kering sangat berdebu.

Pendidikan dasar sampai dengan menengah memiliki tujuan untuk menanamkan karakter kepada peserta didik. Kegiatan pendidikan tidak hanya kegiatan kelas, melainkan juga kegiatan luar kelas yang membutuhkan lapangan yang cukup representatif.

Aktifitas siswa seperti upacara bendera, olah raga, ekstrakurikuler luar kelas seperti pramuka dan lain-lain tidak dapat berjalan maksimal. Apabila kondisi tersebut dipaksakan untuk dilakukan, dalam kondisi basah pada musim penghujan lapangan akan becek dan tanah lengket di sepatu. Apabila musim kemarau, debu yang dihasilkan dari aktifitas siswa dapat mengganggu pernafasan.

Aktivitas olah raga siswa berdampak pada tingkat kesehatan dan kebugaran dimana pada akhirnya dapat meningkatkan kualita spembelajaran mereka di kelas. Agus (2010) di dalam sebuah seminar menyampaikan bahwa olah raga yang dilakukan setidaknya 3 kali seminggu dengan durasi waktu 10 menit terus menerus, menggerakkan lebih dari $90 \%$ otot tubuh serta intensitas latihan $70-80 \%$ DN MAX dapat meningkatkan kesehatan tubuh. Santoso dan Anandaputra, di dalam penelitiannya di SMAN 5 Depok menyampaikan bahwa terdapat hubungan yang bermakna antara intensitas olah raga dengan daya konsentrasi belajar siswa. Miswari (2015), menyampaikan bahwa fasilitas olah raga dan ruang terbuka hijau dapat digunakan sebagai wadah interaksi antar masyarakat dan mengurangi beban rutinitas masyarakat yang padat.

Lokasi lapangan olah raga bola voli SMK Aviasi Branti yang berada di halaman depan sekolah sangat memungkinkan untuk digunakan bersama dengan masyarakat sekitar sekolah pada waktu-waktu sekolah tidak beroperasi, misalkan sore hari dan pada saat kegiatan sekolah libur. Lokasi sangat mudah diakses oleh warga sekitar yang merupakan pemukiman warga yang cukup padat. Fungsi ini juga sekaligus menjadi pagar sosial sekolah dari ancaman keamanan sekolah dari warga lingkungan sekitar mengingat ada rasa memiliki warga sekitar atas fasilitas yang turut mereka manfaatkan. Interaksi atar sekolah dan masyarakat ini merupakan hal yang sangat penting dalam menjaga keberlangsungan dan kondusifitas pelaksanaan kebiatan belajar mengajar siswa di sekolah

Namun demikian kondisi lapangan bola voli yang ada saat ini masih dalam bentuk tanah timbunan dimana ketika musim penghujan tanah menjadi becek dan lengket serta memungkinkan tergerus oleh aliran air hujan, sedangkan ketika musim kemarau datang, 
menjadi berdebu yang cukup mebahayakan bagi kesehatan pernafasan baik oleh siswa, guru, dan masyarakat yang melakukan aktivitas melewati lapangan bola voli tersebut. Kondisi ini memerlukan perbaikan dengan cara meningkatkan lapangan tanah liat tersebut menjadi lebih bersih dan lebih kuat serta ramah lingkungan. Peningkatan lapangan bola voli dari tanah liat menjadi paving block merupakan usulan yang diajukan oleh SMK Aviasi Branti kepada Politeknik Penerbangan Indonesia dalam bentuk kegiatan penngabdian kepada masyarakat.

Yuliawati (2012), menyampaikan bahwa perguruan tinggi sebagai masyarakat ilmiah dituntut untuk berperan secara aktif positif dalam memecahkan permasalahan yang dihadapi masyarakat. Proses perubahan yang terjadi di masyarakat dapat diikuti dengan pelaksanaan tri dharma perguruan tinggi yang langsung dapat dinikmati dan menyelesaikan masalah-masalah yang nyata dihadapi oleh masyarakat. Salah satu kegiatan tri dharma perguruan tinggi yang sangat relevan dalam membantu dan turut terlibat di dalma penyelesaian masalah-masalah di masyarakat adalah kegiatan pengabdian kepada masyarakat. Lian (2019), dalam penelitiannya menemukan bahwa pada dasarnya dosen dan mahasiswa pada perguruan tinggi sudah mulai melek terhadap tanggungjawabnya di dalam tri dharma perguruan tinggi sebagai kegiatna dasar dari seluruh aktivitas yang ada di dalam perguruan tinggi yang harus terus dikembangkan untuk menghasilkan karya yang bermanfaat bagi masyarakat.

Kegiatan pengabdian kepada masyarakat yang dilakukan oleh dosen Politeknik Penerbangan Indonesia (PPI) Curug di SMK Aviasi Branti - Lampung dalam rangka menunjukkan perannya dalam memberikan kontribusi nyata bagi masyarakat pendidikan di bidang penerbangan. Pemilihan pemasangan paving block untuk meningkatkan kualitas lapangan olah raga bola voli di SMK Aviasi Branti - Lampung merupakan kegiatan pengabdian kepada masyarakat yang tidak saja berdampak pada siswa namun juga berdampak pada masyarakat sekitar sekolah.

\section{Metode}

Palaksanaan kegiatan pengabdian kepada masyarakat pemasangan paving block pada lapangan upacara di SMK Aviasi Branti - Lampung merupakan salah satu bentuk kegiatan pengabdian kepada masyarakat yang diatur di dalam ruang lingkup bidang kesejahteraan yang berdampak baik secara langsung maupun tidak langsung terhadap masyarakat di lingkungan Kampus PPI Curug dan bandara, dalam hal ini adalah Bandar Udara Radin Inten II Lampung. Kegiatan pengabdian kepada masyarakat ini dilakukan oleh 5 orang dosen dan tenaga pengajar PPI Curug yang diajukan melalui Progran Studi D III Teknik Bangunan dan Landasan sesuai dengan kompetensinya. Pelaksanaan persiapan dilakukan secara daring sedangkan pelaksanaan pemasangan paving block dilaksanakan selama 2 hari pada tanggal 4 dan 5 Desember 2020 dibantu oleh tenaga profesional setempat beserta civitas akademika SMK Aviasi Branti Lampung. Pengadaan material yang dibutuhkan dalam rangka pemasangan paving block dilakukan di sekitar lokasi dengan pertimbangan dapat memberikan dampak perekonomian masyarakat sekitar lokasi pelaksanaan kegiatan pengabdian kepada masyarakat.

Pemasangan paving block mengikuti standar SNI dengan berpedoman pada SNI03-0691-1996 tentang Bata Beton (Paving Block) dan SK SNI T-04-1990-F. Pembuatan gambar kerja dan perencanaan lainnya dilaksanakan di PPI Curug, sedangkan pelaksanaan dan pengawasan dilakukan secara langsung oleh Tim Pengabdian Kepada Masyarakat di lokasi SMK Aviasi Branti 


\section{Hasil dan Pembahasan}

\section{Standar Pemasangan Paving Block}

Frick, H. \& Koesmartadi, Ch. (1999) mendefinisikan paving block adalah adukan kering yang dibuat dengan cara pemadatan dantersusun dari campuran pasir dan semen portland. SII.0819-83, mendefinisikan paving block atau bata beton adalah suatu komposisi bahan bangunan yang terbuat dari campuran semen portland atau bahan perekat hidrolis lainnya, air dan agregat dengan atau tanpa tambahan lainnya yang tidak mengurangi mutu beton tersebut. SK SNI T-04-1990F, paving block adalah segmen-segmen kecil yang terbuat dari beton segi empat atau segu banyak yang dipasang sedemikian rupa sehingga saling mengunci. Apriani dan Rahardyan (2011) mendefinisikan bahwa paving block merupakan sebuah produk bahan bangunan yang dibuat dari campuran agregat halus, agregat kasar, abu batu, semen, dan air yang digunakan sebagia salah satu alternatif penutup atau perkerasan tanah, biasa dikenal dengan istilah bata beton.

Standar mutu yang harus dipenuhi paving block ditetapkan oleh SNI 03-0691-1996 sebagiamana disampaikan oleh Putra, Kurniawandy, Azhari, adalah:

1. Sifat tampak paving block untuk lantai harus mempunyai bentuk yang sempurna, tidak terdapat retak-retak dan cacat, bagian sudut dan rusuknya tidak mudah direpihkan dengan kekuatan jari tangan,

2. Bentuk dan ukuran paving block untuk lantai tergantung dari persetujuan antara pemakai dan produsen. Setiap produsen memberikan penjelasan tertulis dalam leaflet mengenai bentuk, ukuran, dan konstruksi pemasangan paving block untuk lantai,

3. Penyimpangan tebal paving block untuk lantai diperkenankan kurang lebih $3 \mathrm{~mm}$,

4. Paving block untuk lantai harus mempunyai kekuatan fisik seperti Gambar 1 berikut:

\begin{tabular}{|c|c|c|c|c|c|}
\hline \multirow{2}{*}{ Mutu } & \multicolumn{2}{|c|}{$\begin{array}{l}\text { Kuat Tekan } \\
\text { (MPa) }\end{array}$} & \multicolumn{2}{|c|}{$\begin{array}{c}\text { Ketahanan Aus } \\
\text { (mm/menit) }\end{array}$} & \multirow{2}{*}{$\begin{array}{c}\text { Penyerapan } \\
\text { Air Rata- } \\
\text { Rata Maks. } \\
(\%)\end{array}$} \\
\hline & $\begin{array}{c}\text { Rata- } \\
\text { rata }\end{array}$ & Min & $\begin{array}{l}\text { Rata- } \\
\text { rata }\end{array}$ & Min & \\
\hline A & 40.0 & 35.0 & 0.0090 & 0.103 & 3 \\
\hline B & 20.0 & 17.0 & 0.1300 & 1.149 & 6 \\
\hline $\mathrm{C}$ & 15.0 & 12.5 & 0.1600 & 1.184 & 8 \\
\hline D & 10.0 & 8.5 & 0.2190 & 0.251 & 10 \\
\hline
\end{tabular}

Gambar 1. Kekuatan fisik paving block Sumber: SNI 03-0691-1996

Penggunaan paving block untuk lantai atau jalan semakin banyak digunakan oleh masyarakat karena banyak hal, diantaranya adalah:

1. Pelaksanaannya mudah dan tidak memerlukan alat berat serta dapat diproduksi secara masal,

2. Pemeliharaan mudah dan dapat dipasang kembali setelah dibongkar

3. Tahan terhadap beban statis, dinamis dan kejut,

4. Tahan terhadap tumpahan bahan pelumas dan pemanasan oleh mesin kendaraan

Namun demikian penggunaan paving block juga memiliki beberapa kelamahan diantaranya mudah bergelombang bila pondasinya tidak kuat dan kurang nyaman untuk kendaraan dengan kecepatan tinggi bila diaplikasikan pada jalan raya, sehingga lebih cocok digunakan pada lingkungan pemukiman dan perkotaan yang padat.

Penggunaan paving block untuk lantai atau jalan semakin banyak digunakan oleh masyarakat karena banyak hal, diantaranya adalah: 
1. Pelaksanaannya mudah dan tidak memerlukan alat berat serta dapat diproduksi secara masal,

2. Pemeliharaan mudah dan dapat dipasang kembali setelah dibongkar

3. Tahan terhadap beban statis, dinamis dan kejut,

4. Tahan terhadap tumpahan bahan pelumas dan pemanasan oleh mesin kendaraan

Namun demikian penggunaan paving block juga memiliki beberapa kelamahan diantaranya mudah bergelombang bila pondasinya tidak kuat dan kurang nyaman untuk kendaraan dengan kecepatan tinggi bila diaplikasikan pada jalan raya, sehingga lebih cocok digunakan pada lingkungan pemukiman dan perkotaan yang padat.
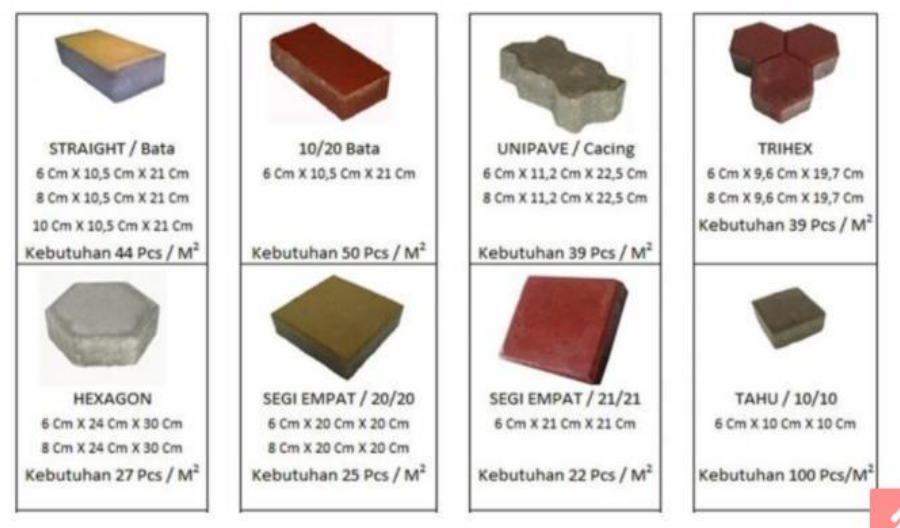

Gambar 2. Bentuk dan spesifikasi paving blok

Sumber: https://indonusa-conblock.com/model-paving-block-di-indonesia

Langkah-langkah pemasangan paving block dapat dilakukan sebagai berikut:

Sebelum paving block dipasang, pastikan struktur lahan yang akan dipasang paving block dalam keadaan benar-benar padat. Apabila belum padat, dapat dipadatkan terlebih dahulu menggunakan mesin roller (wales) atau stamper kuda. Hal ini dilakukan untuk menjaga agar tanah yang telah dipasang oleh paving block tidak amblas atau longsor.

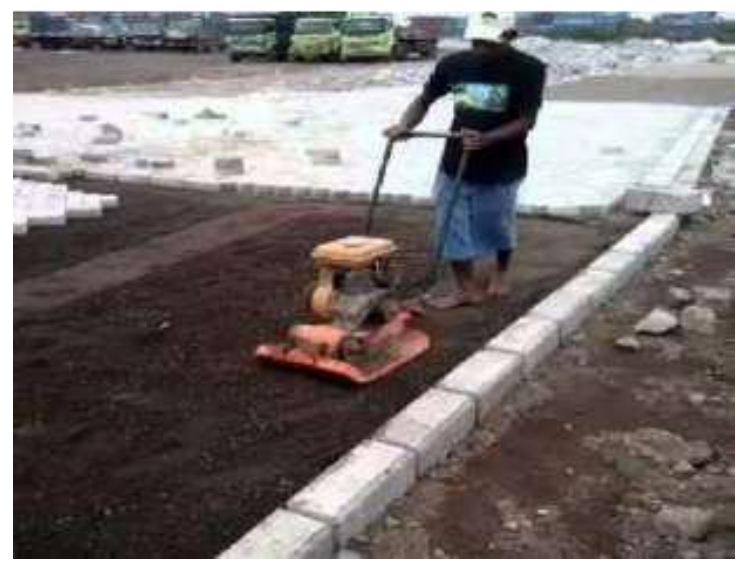

Gambar 3. Penggunaan stamper kuda untuk pemadatan lahan Sumber: https://kotaku.pu.go.id

1. Lapisan Subgrade

Subgrade atau lapisan tanah paling dasar harus diratakan terlebh dahulu sehingga mempunyai profil dengan kemiringan sama dengan yang diperlukan untuk kemiringan drainage (water run off) yaitu minimal 1,5\%. Subgrade atau lapisan tanah ini harus dipadatkan sebelum pekerjaan subbase dilaksanakan sesuai dengan spesifikasi teknis yang 
dibutuhkan. Kualitas subgrade ini sangat penting untuk kekuatan landasan area paving block nantinya.

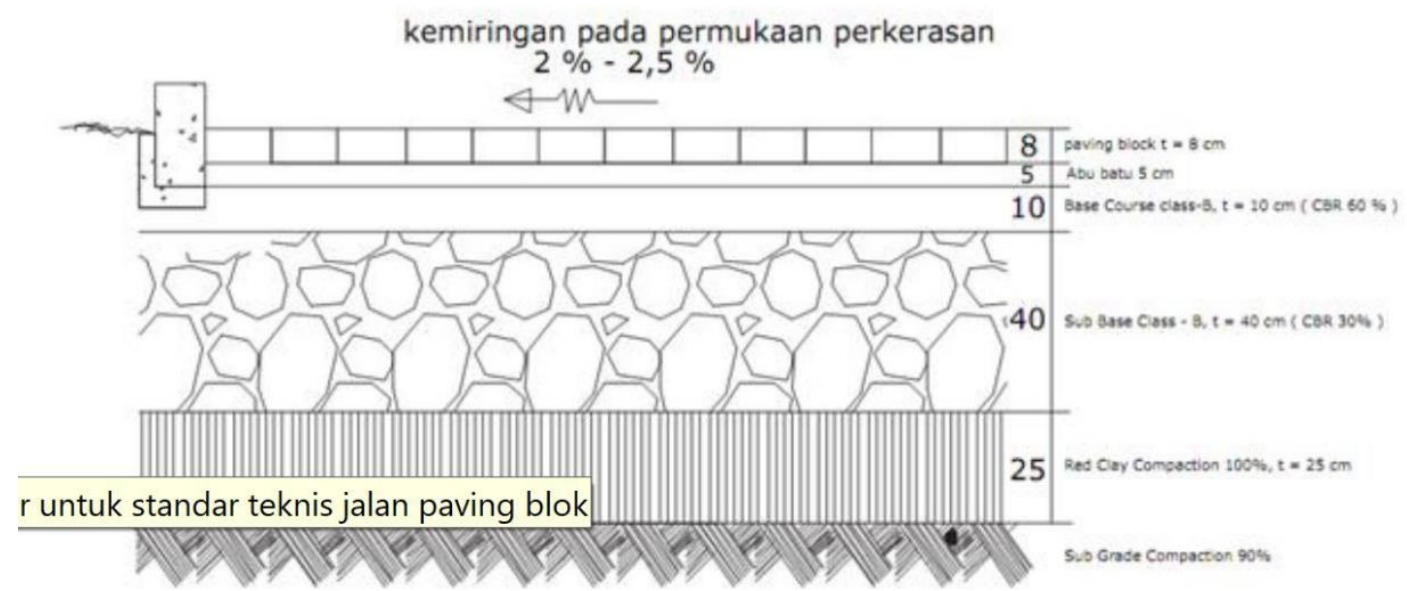

Gambar 4. Standar pemasangan paving block Sumber : SK SNI T-04-1990-F

2. Lapisan Subbase

Pekerjaan lapisan subbase harus disesuaikan dengan gambar dan spesifikasi teknis yang dibutuhkan. Profil lapisan permukaan subbase juga harus mempunyai minimal kemiringan $2 \%$. Kemiringan ini sangat penting untuk jangka panjang kestabilan paving block.

3. Kanstin Beton / Penguat Tepi

Kanstin beton atau penguat tepi atau kerb harus sudah dipasang sebelum pemasangan paving dilakukan. Hal ini dilakukan untuk menahan paving pada tiap sisi agar paving tidak bergeser-geser sehingga hasil pemasangan paving akan terlihat lebih rapi.

4. Pekerjaan Pemasangan Paving Block

- Pastikan permukaan lahan yang akan dipaving dalam kondisi rata;

- Pasang kanstin beton sebagai pengunci paving block, agar paving block yang sudah dipasang tidak bergeser

- Gelar abu batu atau pasir mengikuti kemiringan yang telah ditentukan kemudian ratakan dengan menggunakan jidar kayu

- Lakukan pemasangan paving block dengan cara maju kedepa, sementara pekerja pemasang paving block berada di atas paving yang telah terpasang

- Untuk tepian / sudut-sudut yang belum terpasang paving block (las-lasan), potong paving block lagi dengan menggunakan alat pemotong paving block / paving block cutter

- Setelah lahan $100 \%$ sudah terpasang paving block, selanjutnya lakukan pengisian antar naat paving block tersebut (pengisian joint filler) dengan menggunakan abu batu / pasir

- Bersihkan area lahan yang telah terpasang paving block darisisa=sisa abu batu

- Pekerjaan pemasangan paving block dinyatakan sudah selesai 
Berikut adalah beberapa contoh pemasangan paving block yang benar pada pedestrian

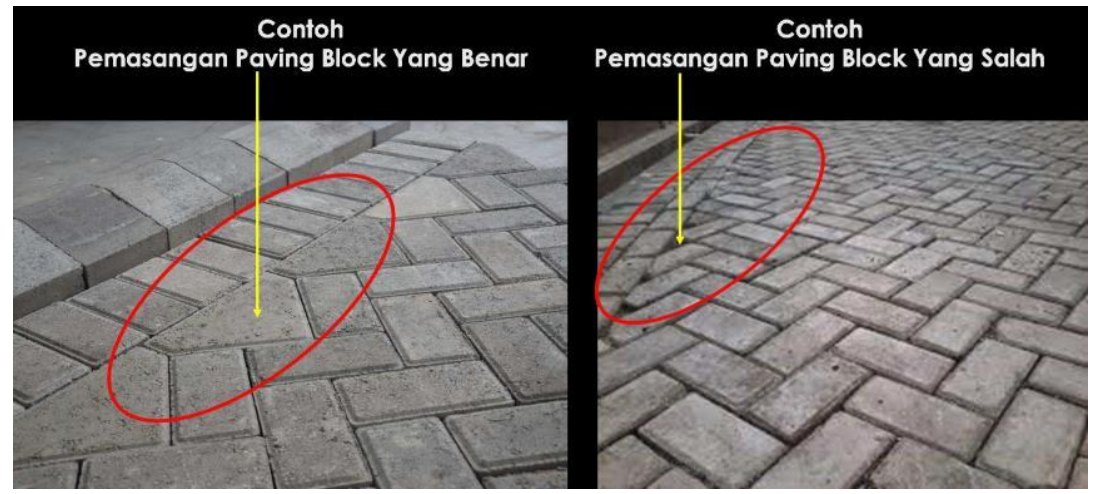

Gambar 5. Pemasangan paving block Sumber: https://kotaku.pu.go.id

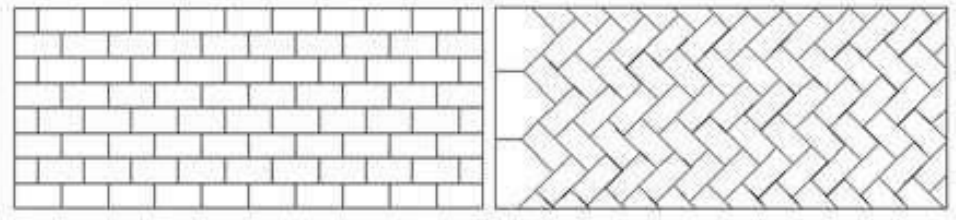

pou susun Bata

DOLA TULANG HKAS AS"

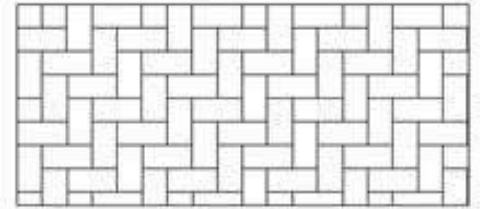

PQLATUEANG DKAN 90

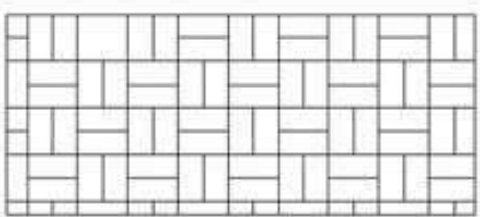

DOLA ANYAM TRXAE

Gambar 6. Contoh pola pemasangan paving block Sumber: www.kotaku .pu.go.id

\section{Pemasangan Paving Block di SMK Aviasi Branti - Lampung}

Pemasangan paving block di SMK Aviasi Branti - Lampung ditujukan untuk meningkatkan kualitas lapangan olah raga bola voli. Berdasarkan standar lapangan bola voli dapat dilihat pada gambar 7 berikut:

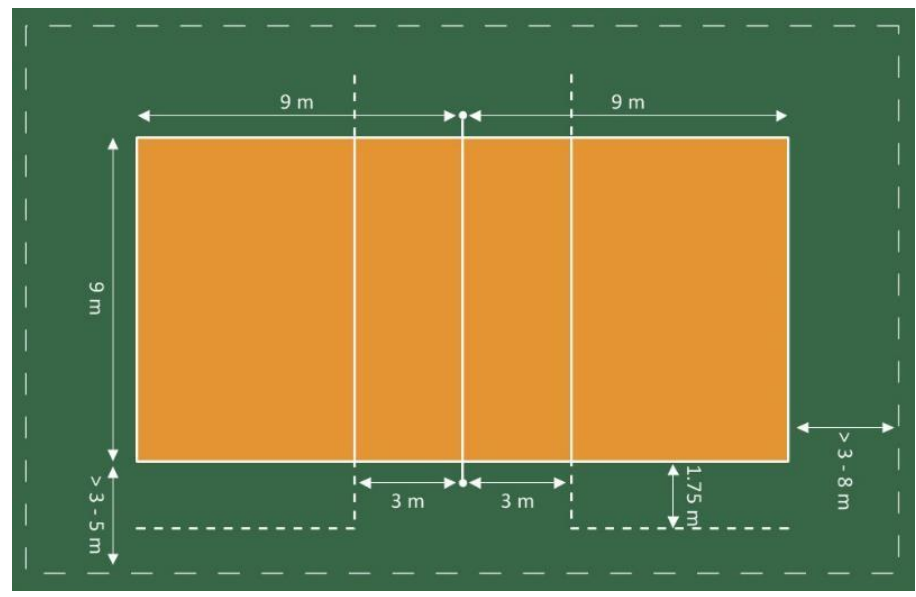

Gambar 7. Standar ukuran lapangan bola voli Sumber: https://kotaku.pu.go.id 
Lapangan bola voli yang akan dipasang paving block di SMK Aviasi Branti - Lampung tidak sesuai dengan standar, namun ukuran lapangan dalam mengikuti gambar standar. Ukuran lapangan bola voli di SMK Aviasi Branti - Lampung dapat dilihat pada gambar 8 berikut:

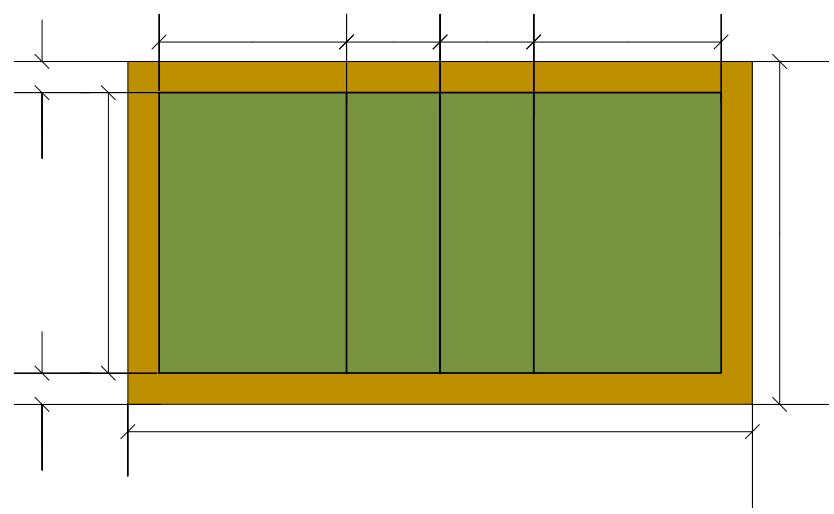

Gambar 8. Ukuran Lapangan Bola Voli SMK Aviasi Branti - Lampung

Ukuran lapangan bola voli yang akan dipasang paving block adalah $220 \mathrm{~m}^{2}$, dengan ukuran panjang 20 meter dan lebar 11 meter. Namun demikian yang dibiayai oleh PPI Curug hanya $116 \mathrm{~m}^{2}$ saja, sedangkan sisanya dibiayai secara mandiri oleh SMK Aviasi Branti.
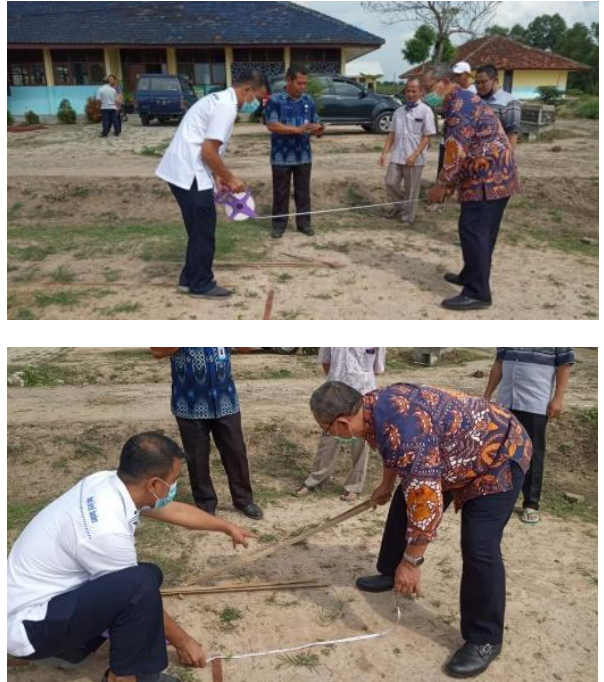
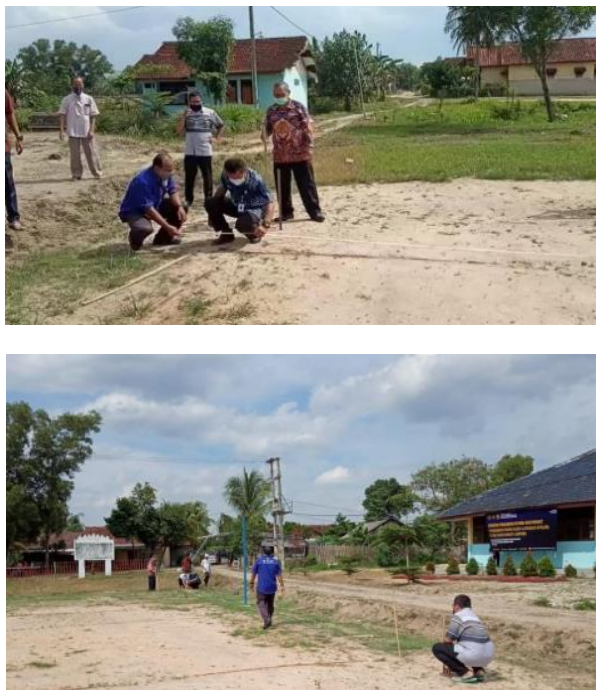

Gambar 9. Pengukuran ulang lokasi pemasangan paving block

Kondisi sebelum pemasangan lapangan upacara aviasi branti sudah digunakan sehingga pada posisi subgrage sudah padat dan tidak membutuhkan pemadatan. Namun demikian memerlukan pembersihan dari rumput yang sudah tumbuh pada beberapa sudut lapangan. Pembersihan juga dilakukan untuk mengambil garis pembatas eksisting yang terbuat dari pasangan batu bata merah. Pembersihan ini dilakukan juga dalam rangka membuat struktur subgrade menjadi rata sekaligus membuat kemiringan yang sesuai sebagai arah aliran air hujan yang mungkin terjadi. Kegiatan pembersihan ini dibantu oleh civitas akademika SMK Aviasi Branti.

Langkah selanjutnya berdasarkan standar yang ada adalah pasang pembatas/kanstin. Kanstin/pembatas ini nantinya akan dipasang berupa batu bata merah dengan adukan semen. 

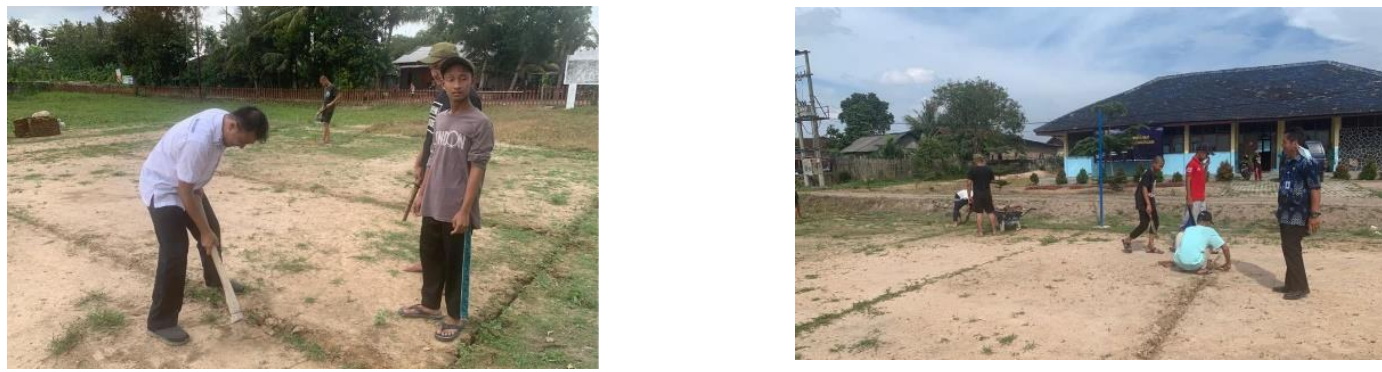

Gambar 10. Pembersihan lapisan subgrade
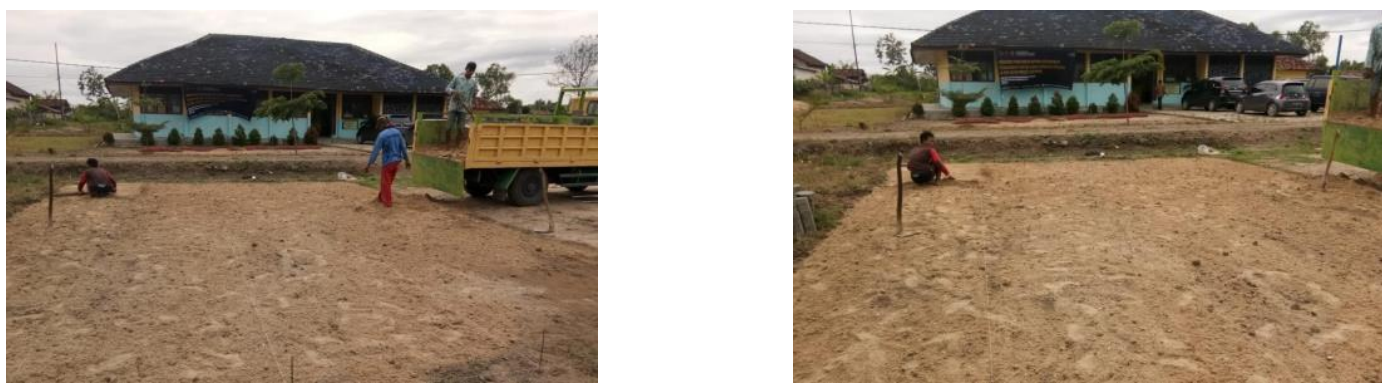

Gambar 11. Penggelaran pasir

Langkah selanjutnya adalah pemadatan dilanjutkan dengan pemasangan paving block. Paving block yang digunakan berbentuk heksagonal dengan tingkat ketebalan $8 \mathrm{~cm}$.
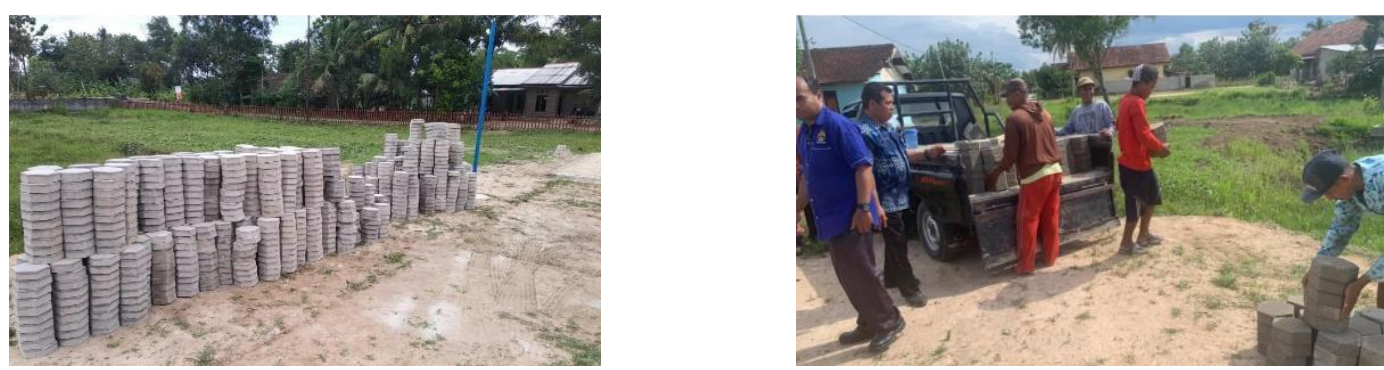

Gambar 12. Model paving block yang dipasang

Sebelum dilaksanakan pemasangan paving block, Tim Pelaksana Kegiatan Pengabdian Kepada Masyarakat PPI Curug melakukan sosialisai tata cara pemasangan paving block kepada civitas akademika SMK Aviasi Branti - Lampung.
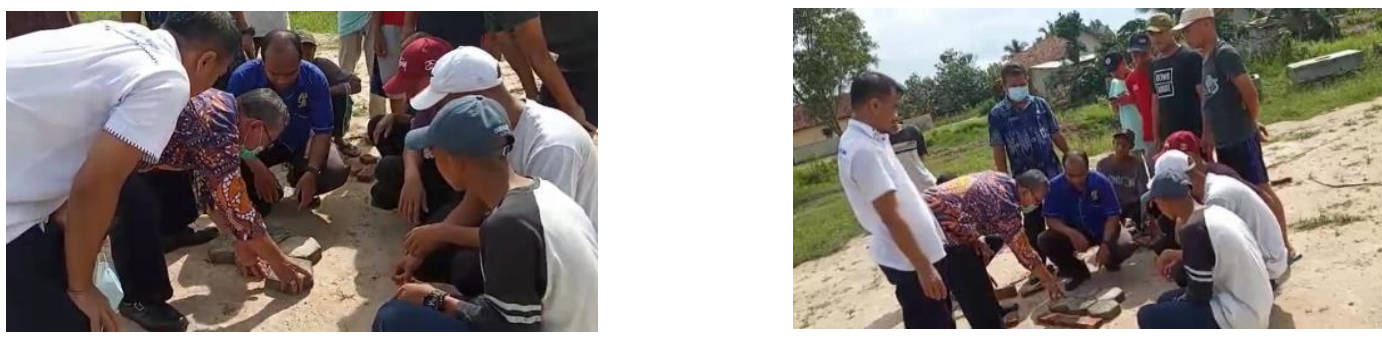

Gambar 13. Sosialisasi pemasangan paving block oleh tim

Pemasangan paving block dibantu oleh tenaga profesional dari lokasi untuk membantu hasil yang lebih memuaskan dan mempercepat pelaksanaan kegiatan pengabdian kepada masyarakat tanpa mengurangi tujuan pelaksanaan pengabdian kepada masyarakat. Sebagaimana disampaikan didalam standar pemasangan paving block dilaksanakan maju ke 
depan dimana orang yang memasang paving block berada di atas paving block yang sudah terpasang. Hal ini berbeda dengan pemasangan beton yang dilakukan mundur. Pemasangan paving block untuk luas $220 \mathrm{~m} 2$ dapat dilakukan dalam waktu 2 hari kalender, mengingat seuruh bahan sudah tersedia dantelah melalui pengecekan dan pengawasan yang dilakukan oleh pihak SMK Aviasi Branti - Lampung. Pengawasan ini dilakukan dalam rangka memperhatikan kuncian pada pemasangan antar paving block mengingat toleransi pembuatan yang ada. Ini diantisipasi memperhatikan temuan penelitian (Mudiyono dkk, 2019) yang menemukan bahwa interlocking pada paving block mempengaruhi kelendutan yang terjadi pada pemasangan paving block. Hal ini akan berdampak pada usia pemsangan paving block yang tidak lama. Evaluasi dan monitoring yang akan dilakukan oleh PPI Curug terhadap pelaksanaan pemasangan paving block ini pada periode berikutnya akanmeunjukkan kualitas dari pemilihan pavingblock dan teknik pemasangannya.
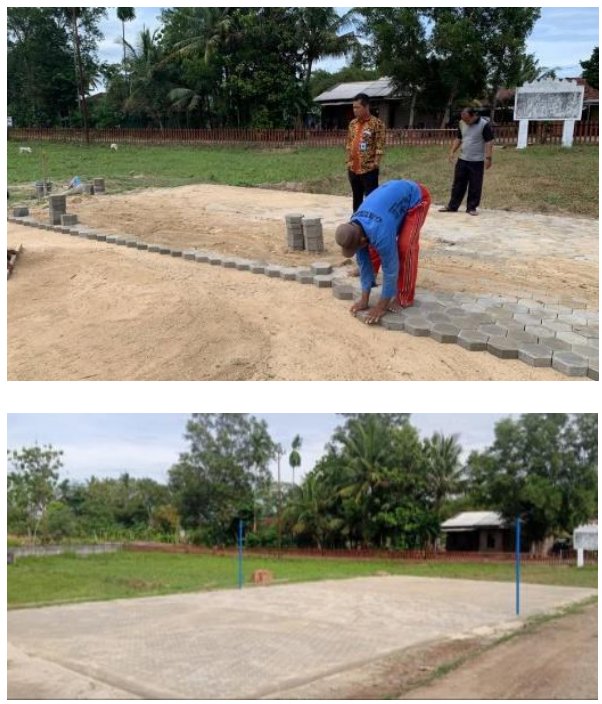
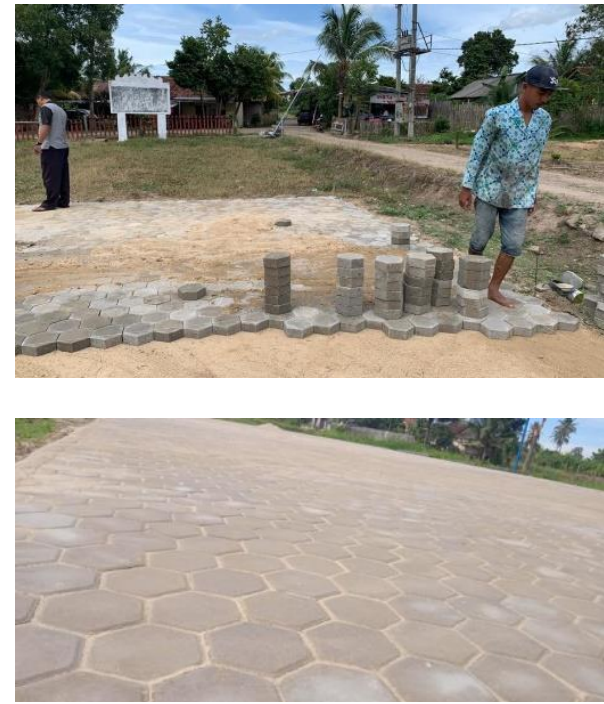

Gambar 14. Proses pemasangan paving block dan hasilnya

Sebelum melakukan perjalanan pulang ke Tangerang, Tim Pelaksana Kegiatan Pengabdian Masyarakat PPI Curug menyempatkan diri berfoto bersama Civitas Akademika SMK Aviasi Branti - Lampung.

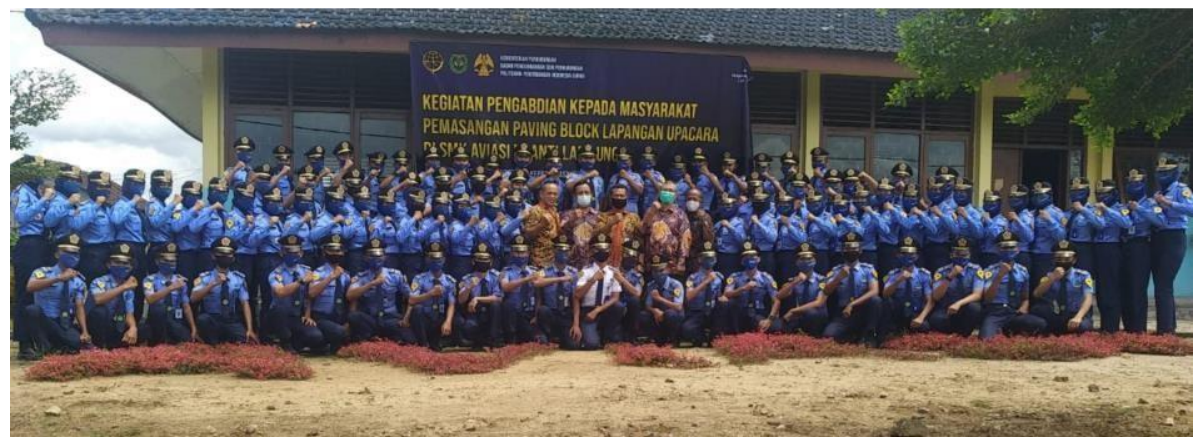

Gambar 15. Foto bersama siswa SMK Aviasi Branti - Lampung 


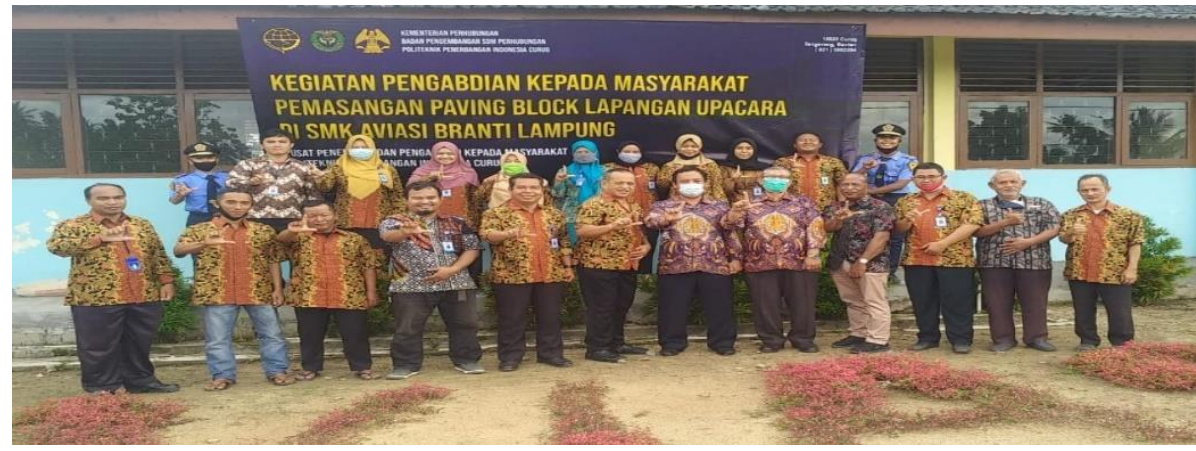

Gambar 16. Foto bersama Guru SMK Aviasi Branti - Lampung

\section{Kesimpulan}

Kegiatan Pengabdian Kepada Masyarakat Dosen PPI Curug di SMK Aviasi Branti Lampung disambut antusias oleh Civitas Akademika SMK Aviasi Branti - Lampung. Keberadaan lapangan olah raga bola voli tidak lagi menimbulkan becek di musim penghujan dan debu di musim kemarau. Lapangan olah raga ini juga dapat dimanfaatkan untuk kegiatan lain seperti ekstrakurikuler, apel dan lain-lain. Lapangan olahraga tersebut juga dapat dimanfaatkan oleh sekolah dalam rangka berinteraksi dengan lingkungan dengan cara memberikan kesempatan kepada masyarakat umum untuk turut memanfaatkan lapangan tersebut sepanjang tidak mengganggu jadual kegiatan siswa.

Kegiatan pengabdian masyarakat tersebut juga mampu menjadi ajang praktek bagi Dosen PPI Curug untuk berbagi kompetensi dengan masyarakat terutama dalam hal standarisasi pemasangan paving blok untuk kebutuhan lapangan olah raga. Kegiatan seperti ini akan semakin baik jika melibatkan lebih banyak unsur masyarakat, namun demikian panc=demi Covid-19 yang masih berlangsung membuat kegiatan yang seharusnya lebih banyak melibatkan masyarakat menjadi terbatas.

\section{Penghargaan/Ucapan terima kasih}

Ucapat terima kasih dan penghargaan diucapkan kepada Pelaksana Tugas Direktur Politeknik Penerbangan Indonesia, Kepala Pusat Penelitian dan Pengabdian Kepada Masyarakat, Ketua Program Studi Diploma III Teknik Bangunan dan Landasan PPI Curug, atas dukungannya kepada untuk menyelesaikan kegiatan pengabdian kepada masyarakat ini. Kepala SMK Aviasi Branti - Lampung beserta seluruh civitas akademikanya, serta seluruh tim yang telah banyak memberikan peran dalam terselenggaranya kegiatan pengabdian kepada masyarakat ini.

\section{Daftar Pustaka}

Agus, Apri. (2010). Pentingnya peran olahraga dalam menjaga kesehatan dan kebugaran tubuh. Naskah tidak dipublikasikan. Fakultas Ilmu Kesehatan, Universitas Negeri Padang, Padang. Diakses dari http://repository.unp.ac.id/666/1/APRI\%20AGUS_295_10.pdf pada 19 Maret 2021, 13:40

Apriani I.N.D., Rahardyan B., (2011). Pemanfaatan limbah spent catalyst sebagai campuran paving block dan batako. Jurnal Teknik Lingkungan, 17(2).

Frick, H. \& Koesmartadi, Ch. (1999). Ilmu Bahan Bangunan. Yogyakarta: Penerbit Kanisius Lian, Bukman (2019). Tanggungjawab Tridharma Perguruan Tinggi menjawab kebutuhan 
masyarakat. Prosiding Seminar Nasional Pendidikan Program Pascasarjana Universitas PGRI Palembang 03 Mei 2019. Diakses dari https://jurnal.univpgripalembang.ac.id/index.php/Prosidingpps/article/download/2965/2791\# pada 19 Maret 2021, 14:09

Miswari, (2015). Sarana olahraga dengan penekanan ruang terbuka hijau sebagai wadah interaksi sosial masyarakat di Kabupaten Kubu Raya. Jurnal online mahasiswa Arsitektur Universitas Tanjungpura, 3(2), 1-18.

Mudiyono, R., Tsani, N.S., Putra, A.P., Adha, K.M., (2019). Analisis pengaruh bentuk paving block terhadap kelendutan perkerasan jalan. Jurnal Reviews in Civil Engineering, 3(1), 12-19.

Diakses

dari https://jurnal.untidar.ac.id/index.php/civilengineering/article/view/1231/832 pada 19 Maret 2021, 18:04

Putra, A., Kurniawandy, A., Azhari ( ). Pengaruh variasi bentuk paving blok terhadap kuat tekan. Jurusan Teknik Sipil Fakultas Teknik Universitas Riau.

Santoso, Slamet S., \& Anadaputra (2017). Hubungan Intensitas Olahraga dengan Daya Konsentrasi Belajar Siswa/Siswi Kelas 10 dan 11 SMAN 5 Depok Jawa Barat. Jurnal Kedokteran dan Kesehatan, 13(1):1. https://www.researchgate.net/deref/http\%3A\%2F\%2Fdx.doi.org\%2F10.24853\%2Fjkk. 1 3.1.1-8. Diakses pada 19 Maret 2021, 13:51

Yuliawati, Sri, (2012). Kajian implementasi Tri Dharma Perguruan Tinggi sebagai fenomena pendidikan tinggi di Indonesia. Jurnal Ilmiah Widya. Diakses dari https://ejournal.jurwidyakop3.com/index.php/majalah-ilmiah/article/view/36, pada 19 Maret 2021, 14:03

SNI.0819-88. Standar Industri Indonesia. Bata Beton Untuk Lantai

SK SNI T-04-1990 F. Standar Nasional Indonesia. Tata Cara Pemasangan Blok Beton Terkunci Untuk Permukaan Jalan. 